\title{
APPLYING CLASSROOM DESIGN CONCEPT TO INCREASE THE STUDENTS' INTEREST IN LEARNING ENGLISH
}

\author{
Misba $^{1}$, Syarifuddin Tjali ${ }^{2}$ \\ Institut Agama Islam Negeri (IAIN) Parepare ${ }^{12}$ \\ misakimisbadesu@gmail.com ${ }^{1}$
}

\begin{abstract}
Classroom design is one of the important components in the learning process in the school which demands high innovation and creativity during the class. On the other hand, the teacher as a supervisor in the classroom should pay more attention to the influenced factors of the students' interest. One of the influenced factors comes from classroom design or environment. In this case, the researcher found that the teachers in SMA Negeri 7 Pinrang have been improving their teaching methods but they do not concern the classroom design. The objective of this research is to know whether the classroom design influences the students' interest or not in English learning activity of SMA Negeri 7 Pinrang. In doing this research, the researcher held intensive meeting related to designing the classroom to raise the students' interest in learning English and giving a questionnaire to the students to know their response. The result of this research showed there was a positive and significant influence of classroom design to the students' interest.
\end{abstract}

Keywords: classroom design, students' interest, English learning

\section{Introduction}

The teacher as the supervisor in the classroom should pay more attention to the influenced factors of the students' interest in order to improve the students' performance in learning activity. One of the factors is the external factors such as the school environment. A good environment will give the students better psychological condition to study. It seems very essential towards the learning activity in the classroom. Therefore, the teacher are demanded to present a good environment in the classroom during the learning process. The role of the teacher as the educator is not only thinking about the method of teaching but also thinking about the way to make a good classroom condition and situation mentally or physically.

A research "How Classroom Design Affects Students Engagement" by Steel Education, it has been found that classroom designed for active learning - i.e., where physical space supports a focus on engaging experiences for students and faculty - have a 
significant effect on student engagement. As a result of the development of the evaluation instrument and the managed research program, decision makers at educational institutions, architects and designers can be assured that investments in solutions intentionally designed to support active learning can create more effective classrooms and higher student engagement. Furthermore, there is now evidence that these classrooms encourage and enable educators to practice active learning methods (Steelcase Education, 2014).

Having a good classroom environment physically can be created by making a good classroom design or architecture. A growing body of scientific work has revealed the physical classroom environment's important - and sometimes surprising - effects on students' academic performance. Evidence demonstrates those classrooms' structural features (e.g., noise, lighting) and symbolic features (e.g., everyday objects that signal who belongs in the classroom) can facilitate or hinder student learning and achievement (SapnaCheryan, 2014). The statements emphasize that the good classroom design should be conducted in the school. Besides there are many teachers only focusing on the way to teach while forgetting the classroom design.

Conducting a good classroom design can be held in all schools whether in the elementary school or high school. Especially in senior high school, the researcher found some cases at SMA Negeri 7 Pinrang relating to classroom design problem. The researcher saw the development of the school has grown well for year to year. The school has improved the quality both of the teacher and the building rapidly. On the other hand, the teachers at the school has been improving their teaching methods in the classroom and providing teaching tools but no concerning on the classroom design. In relating the problem, this research is aimed at finding out whether classroom design influences the students' interest in English learning activity of SMA Negeri 7 Pinrang.

The significances of the research are expected to be useful for many people. For the teachers, this research is expected to give information and knowledge about the influence of classroom design to the students' interest in English learning activity. For the students, this research is expected to give many contributions to the students in order the students can realize the good classroom environment for them in learning English then it can increase their interest to study. For other researchers, this research is expected to be useful as a 
reference to conduct a similar research that deals with the same aspect. For the school, the researcher expects this school is able to improve the school environment after knowing the result of this research about classroom design influence towards students' interest in learning English.

\section{Method}

An analysis of research needs an approach to prove the hypothesis that has been formulated through collecting the data. The research design applied in this research is called quantitative study because it uses numbers or statistics. There are two variables of this research, they are; classroom design which is signed as (X) and the students' interest which is signed as $(\mathrm{Y})$ where the researcher tries to find out the relationship between the $\mathrm{X}$ variable and the $\mathrm{Y}$ variable.

The location of this research dwelt at SMA Negeri 7 Pinrang. The population is the second and the third-grade students of SMA Negeri 7 Pinrang in academic year 2016/2017. Based on the current data, the researcher had chosen all of the students of SMA Negeri 7 Pinrang to become the population of this research. There are 13 classes as the population of this research where there are six classes of the eleventh grade and six classes of the twelfth grade with the varying number of students in each class.

The researcher didn't attach the data of the tenth-grade students because this research needed valid data. The population of this research only refers to the eleventh and the twelfth-grade students at the whole in the academic year 2016/2017 so the researcher takes the sample as the representative of the population.

In this research, the researcher applied the unrestricted random sampling technique to take the sample because the population is homogeneous. The researcher determines the number of sample for every class into eight students, so all of the class had the same opportunity to be a member of the sample. The researcher took the eight samples in every class randomly by using a lottery. All of the students in a class were marked with the numbers and the researcher took eight numbers that have been chosen as the samples. The same technique was applied in the other classes until all of the expected samples are obtained. 
In obtaining the data, the researcher used the direct observation technique to obtain the data. The object of the observation is the students during the learning activity in every meeting. The researcher observed the students' response attitude in the classroom during the learning process to know the relation of the classroom environment with the degree of students' interest whether the classroom design affects the students' interest or not.

In this research, the researcher used the Likert Scale questionnaire in collecting the data related to the students' interest. The questionnaire was used to get the data of the independent variable and the dependent variable value. There were 24 items of the questionnaire which was divided into two parts where the item number $1-12$ related to classroom design variable and the item number $13-24$ related to the statements about the students' interest.

After the data of this research is collected, the researcher analyzed the data by using the associative-correlative technique is applied. The following steps are:

Find the correlation between the independent variable $(\mathrm{X})$ with the dependent variable (Y). The applied formula is correlation product-moment technique (Sugiyono, 2014). The formula of product-moment correlation that used as follow:

$$
\begin{aligned}
& \qquad r_{x y}=\frac{\sum x y}{\sqrt{\left(\sum x^{2}\right)\left(\sum y^{2}\right)}} \\
& r_{x y}=\text { Coefficient of variable } \mathrm{X} \text { and } \mathrm{Y} \text { correlation } \\
& \sum_{x y}=\text { The sum of multiplication score of } \mathrm{X} \text { and } \mathrm{Y} \\
& \sum_{x^{2}}=\text { The sum of square score of } \mathrm{X} \text { distribution } \\
& \sum_{y^{2}}=\text { The sum of square score of } \mathrm{Y} \text { distribution }
\end{aligned}
$$

Find the regression, by applying the formula:

Where:

$$
Y^{\prime}=a+b X
$$

$\mathrm{Y}^{\prime}=$ Subject in the predicted dependent variable

$a=$ Value of $Y$ if $X=0$ (constant value)

$b=$ Purpose number or coefficient of regression that shows the number of the increasing and decreasing of dependent variable based on the independent variable. If $b(+)$ it means increasing, and if (-) it means decreasing 
$\mathrm{X}=$ Subject in the independent variable which has certain value (independent variable value) (Sugiyono, 2002).

The basis of the interpretation in regression test refer to two matters, the first matter is by comparing the value of $t_{\text {count }}$ with the $t_{\text {table }}$, and the second matter is by comparing the significant value with the probability value 0.05 .Comparing the $t_{\text {count }}$ and the $t_{\text {table }}$ value. If the $t_{\text {count }}$ value is bigger than the $t_{\text {table }}$ value, it means the independent variable influence the dependent variable. If the $t_{\text {count }}$ isn't bigger than the $t_{\text {table }}$ value, it means the independent variable doesn't influence the dependent variable.Comparing the significant value with the probability 0.05 . If the significance value isn't more than the probability value 0.05 , it means the independent variable influence the dependent variable significantly. If the significance value is more than the probability value 0.05 , it means the independent variable doesn't influence the dependent variable significantly.

Conducting the calculation by using the current formula it can be realized whether there is a positive influence or not and has a regression equation.

\section{Result}

The description below explained the result from the questionnaire. The purpose of giving the questionnaire was to get the primary data. This data was intended to know the students' response toward the meeting that has been holding by the researcher to them.

Table 1.The lighting in the classroom gives strong effect to me in learning English

\begin{tabular}{ccccc}
\hline No & Classification & Score & Frequency & Sum of score \\
\hline 1 & Strongly agree (SA) & 5 & 44 & 220 \\
2 & Agree (A) & 4 & 42 & 168 \\
3 & Undecided (U) & 3 & 6 & 18 \\
4 & Disagree (D) & 2 & 3 & 6 \\
5 & Strongly disagree (SD) & 1 & 1 & 1 \\
\hline
\end{tabular}

The data above (item No.1)explained that the lighting in the classroom gave strong effect to 96 students in learning English. Where $413 / 480$ x $100=86,04 \%$. 
Table 2.The noise in the classroom can affect my concentration during English learningprocess

\begin{tabular}{ccccc}
\hline No & Classification & Score & Frequency & Sum of score \\
\hline 1 & Strongly agree (SA) & 5 & 78 & 390 \\
2 & Agree (A) & 4 & 4 & 16 \\
3 & Undecided (U) & 3 & 0 & 0 \\
4 & Disagree (D) & 2 & 1 & 2 \\
5 & Strongly disagree (SD) & 1 & 13 & 13 \\
\hline
\end{tabular}

The data above (item No.2) showed that the noise in the classroom affected their English learning process in the classroom where 421/480 x $100=87.70 \%$.

Table 3.The classroom temperature may affect my activity in English learning process

\begin{tabular}{ccccc}
\hline No & Classification & Score & Frequency & Sum of score \\
\hline 1 & Strongly agree (SA) & 5 & 23 & 115 \\
2 & Agree (A) & 4 & 47 & 188 \\
3 & Undecided (U) & 3 & 19 & 57 \\
4 & Disagree (D) & 2 & 4 & 8 \\
5 & Strongly disagree (SD) & 1 & 3 & 3 \\
\hline
\end{tabular}

The data above (item No.3) showed that the temperature in the classroom may affect the students' activity in learning English. Where 371/480 x $100=77.29 \%$.

Table 4.The air circulation in the classroom can affect my English learning activity

\begin{tabular}{ccccc}
\hline No & Classification & Score & Frequency & Sum of score \\
\hline 1 & Strongly agree (SA) & 5 & 14 & 70 \\
2 & Agree (A) & 4 & 40 & 160 \\
3 & Undecided (U) & 3 & 19 & 57 \\
4 & Disagree (D) & 2 & 18 & 36 \\
5 & Strongly disagree (SD) & 1 & 5 & 5 \\
\hline
\end{tabular}

The data above (item No.4) showed that the air circulation in the classroom may affect the students English learning activity. It based on the data that was gotten from 96 respondents, where $328 / 480 \times 100=68.33 \%$

Table 5.The classroom with good access may affect my readiness in learning English

\begin{tabular}{ccccc}
\hline No & Classification & Score & Frequency & Sum of score \\
\hline 1 & Strongly agree (SA) & 5 & 32 & 160 \\
2 & Agree (A) & 4 & 29 & 116 \\
3 & Undecided (U) & 3 & 25 & 75 \\
4 & Disagree (D) & 2 & 9 & 18 \\
5 & Strongly disagree (SD) & 1 & 1 & 1 \\
\hline
\end{tabular}


The data above (item No.5) showed that the classroom with good access affected the students' readiness in learning English. Where 370/480 x $100=77.08 \%$.

Table 6.The supporting furniture in the classroom can affect my activity in learning

\begin{tabular}{ccccc}
\multicolumn{2}{c}{ English } & & & \\
\hline No & Classification & Score & Frequency & Sum of score \\
\hline 1 & Strongly agree (SA) & 5 & 15 & 75 \\
2 & Agree (A) & 4 & 26 & 104 \\
3 & Undecided (U) & 3 & 14 & 42 \\
4 & Disagree (D) & 2 & 31 & 62 \\
5 & Strongly disagree (SD) & 1 & 10 & 10 \\
\hline
\end{tabular}

The data above (item No.6) showed the supporting furniture in the classroom may affect the students in learning English while it may not give any effect to the other students. Where $293 / 480 \times 100=61.04 \%$.

Table 7.The arrangement of furniture in the classroom affects my comfort in learning

\begin{tabular}{ccccc}
\multicolumn{1}{c}{ English } & & & & \\
\hline No & Classification & Score & Frequency & Sum of score \\
\hline 1 & Strongly agree (SA) & 5 & 15 & 75 \\
2 & Agree (A) & 4 & 38 & 152 \\
3 & Undecided (U) & 3 & 19 & 57 \\
4 & Disagree (D) & 2 & 20 & 40 \\
5 & Strongly disagree (SD) & 1 & 4 & 4 \\
\hline
\end{tabular}

The data above (item No.7) showed that the arrangement of furniture in the classroom affects the students' comfort in learning English. Where 328/480 x $100=68$. $33 \%$.

Table 8.The wall objects in the classroom can affect my performance in learning English

\begin{tabular}{ccccc}
\hline No & Classification & Score & Frequency & Sum of score \\
\hline 1 & Strongly agree (SA) & 5 & 5 & 25 \\
2 & Agree (A) & 4 & 8 & 32 \\
3 & Undecided (U) & 3 & 11 & 33 \\
4 & Disagree (D) & 2 & 44 & 88 \\
5 & Strongly disagree (SD) & 1 & 28 & 28 \\
\hline
\end{tabular}

The data above (item No.8) showed thatthe wall objects did not really affect the students' performance in learning English. Where206/480 x $100=42.91 \%$. 
7nspiring: English Education Gournal

Volume I No 2 September2018

Table 9.The decoration of the classroom may affect my English learning activity during theclass

\begin{tabular}{ccccc}
\hline No & Classification & Score & Frequency & Sum of score \\
\hline 1 & Strongly agree (SA) & 5 & 5 & 25 \\
2 & Agree (A) & 4 & 12 & 48 \\
3 & Undecided (U) & 3 & 14 & 42 \\
4 & Disagree (D) & 2 & 46 & 92 \\
5 & Strongly disagree (SD) & 1 & 19 & 19 \\
\hline
\end{tabular}

The data above (item No.9) showed that the decoration of the classroom may affect some students' English learning activity and may not affect the other students' learning activity. Where $226 / 480 \times 100=47.08 \%$.

Table 10.The seat arrangement in the classroom can affect my activity in learning English

\begin{tabular}{ccccc}
\hline No & Classification & Score & Frequency & Sum of score \\
\hline 1 & Strongly agree (SA) & 5 & 16 & 80 \\
2 & Agree (A) & 4 & 34 & 136 \\
3 & Undecided (U) & 3 & 18 & 54 \\
4 & Disagree (D) & 2 & 23 & 46 \\
5 & Strongly disagree (SD) & 1 & 5 & 5 \\
\hline
\end{tabular}

The data above (item No.10) showed that the seat arrangement in the classroom can affect the students' activity in learning English. Where 321/480 x $100=66.87 \%$.

Table 11.The supporting tools that has been provided in classroom can affect my interest in learning English

\begin{tabular}{ccccc}
\hline No & Classification & Score & Frequency & Sum of score \\
\hline 1 & Strongly agree (SA) & 5 & 36 & 180 \\
2 & Agree (A) & 4 & 25 & 100 \\
3 & Undecided (U) & 3 & 19 & 57 \\
4 & Disagree (D) & 2 & 13 & 26 \\
5 & Strongly disagree (SD) & 1 & 3 & 3 \\
\hline
\end{tabular}

The data above (item No.11) showed that the supporting tools that has been provided in the classroom can affect the students' interest in learning English. Where $366 / 480 \times 100=76.25 \%$ and it categorized as strong. 
7nspiring: English Education Gournal

Volume I No 2 September2018

Table 12.The using of technology in the classroom may increase my interest in English learning activity

\begin{tabular}{ccccc}
\hline No & Classification & Score & Frequency & Sum of score \\
\hline 1 & Strongly agree (SA) & 5 & 60 & 300 \\
2 & Agree (A) & 4 & 31 & 124 \\
3 & Undecided (U) & 3 & 4 & 12 \\
4 & Disagree (D) & 2 & 1 & 2 \\
5 & Strongly disagree (SD) & 1 & 0 & 0 \\
\hline
\end{tabular}

The data above (item No.12) showed that the using of technology in the classroom may increase the students' interest in English learning activity. Where 438/480 x $100=$ $91.25 \%$ and it categorized as very strong.

Table 13.I will be more enthusiast in learning English with the good classroom arrangement

\begin{tabular}{ccccc}
\hline No & Classification & Score & Frequency & Sum of score \\
\hline 1 & Strongly agree (SA) & 5 & 52 & 260 \\
2 & Agree (A) & 4 & 31 & 124 \\
3 & Undecided (U) & 3 & 11 & 33 \\
4 & Disagree (D) & 2 & 2 & 4 \\
5 & Strongly disagree (SD) & 1 & 0 & 0 \\
\hline
\end{tabular}

The data above (item No.13) showed that most ofthe students will be more enthusiast in learning English with good classroom arrangement. Where 421/480 x $100=$ $87.70 \%$ and is categorized as very strong.

Table 14.I will be more focus to learn English in the quiet classroom

\begin{tabular}{ccccc}
\hline No & Classification & Score & Frequency & Sum of score \\
\hline 1 & Strongly agree (SA) & 5 & 88 & 440 \\
2 & Agree (A) & 4 & 7 & 28 \\
3 & Undecided (U) & 3 & 1 & 3 \\
4 & Disagree (D) & 2 & 0 & 0 \\
5 & Strongly disagree (SD) & 1 & 0 & 0 \\
\hline & Total & & 96 & 471 \\
\hline
\end{tabular}

The data above (item No.14) showed that most of the students will be more focus to learn English in the quiet classroom. Where $471 / 480 \times 100=98.12 \%$ and is categorized as very strong. 
Table 15.Iam very interested to learn English in an attractive decorated classroom

\begin{tabular}{ccccc}
\hline No & Classification & Score & Frequency & Sum of score \\
\hline 1 & Strongly agree (SA) & 5 & 52 & 260 \\
2 & Agree (A) & 4 & 39 & 156 \\
3 & Undecided (U) & 3 & 3 & 9 \\
4 & Disagree (D) & 2 & 2 & 4 \\
5 & Strongly disagree (SD) & 1 & 0 & 0 \\
\hline & Total & & 96 & 429
\end{tabular}

The data above (item No.15) showed that the students are mostly interested to learn English in an attractive decorated classroom. Where $429 / 480 \times 100=89.37 \%$ and is categorized as very strong.

Table 16.I am more interested to learn English in a classroom with good environment.

\begin{tabular}{ccccc}
\hline No & Classification & Score & Frequency & Sum of score \\
\hline 1 & Strongly agree (SA) & 5 & 58 & 290 \\
2 & Agree (A) & 4 & 34 & 136 \\
3 & Undecided (U) & 3 & 1 & 3 \\
4 & Disagree (D) & 2 & 1 & 2 \\
5 & Strongly disagree (SD) & 1 & 2 & 2 \\
\hline & Total & & 96 & 433 \\
\hline
\end{tabular}

The data above (item No.16) showed that the classsroom with good environment is able to make the students more interested to learn English. Where 433/480 x $100=90.20 \%$ and is categorized as very strong.

Table 17.I will pay more attention to the English class if the classroom is provided with

\begin{tabular}{ccccc}
\multicolumn{5}{c}{ LCD projector. } \\
\hline No & Classification & Score & Frequency & Sum of score \\
\hline 1 & Strongly agree (SA) & 5 & 30 & 150 \\
2 & Agree (A) & 4 & 37 & 148 \\
3 & Undecided (U) & 3 & 17 & 51 \\
4 & Disagree (D) & 2 & 11 & 22 \\
5 & Strongly disagree (SD) & 1 & 1 & 1 \\
\hline & Total & & 96 & 372
\end{tabular}

The data above (item No.17) showed that most of the students will pay more attention to the English class if the classroom is provided with LCD projector. Where $372 / 480 \times 100=77.5 \%$ and is categorized as strong. 
Table 18.I will pay full attention to the English class that is delivered by the teacher if the classroom is completed with the supporting tools.

\begin{tabular}{ccccc}
\hline No & Classification & Score & Frequency & Sum of score \\
\hline 1 & Strongly agree (SA) & 5 & 30 & 150 \\
2 & Agree (A) & 4 & 46 & 184 \\
3 & Undecided (U) & 3 & 13 & 39 \\
4 & Disagree (D) & 2 & 7 & 14 \\
5 & Strongly disagree (SD) & 1 & 0 & 0 \\
\hline & Total & & 96 & 387
\end{tabular}

The data above (item No.18) showed that the classroom which is completed with the supporting tools can make the students pay full attention to the English class that is delivered by the teacher. Where $387 / 480 \times 100=80.62 \%$ and it categorized as very strong.

Table 19.I will be more active in English learning activity if the classroom is supported with complete tools.

\begin{tabular}{ccccc}
\hline No & Classification & Score & Frequency & Sum of score \\
\hline 1 & Strongly agree (SA) & 5 & 60 & 300 \\
2 & Agree (A) & 4 & 19 & 76 \\
3 & Undecided (U) & 3 & 10 & 30 \\
4 & Disagree (D) & 2 & 7 & 14 \\
5 & Strongly disagree (SD) & 1 & 0 & 0 \\
\hline & Total & & 96 & 420 \\
\hline
\end{tabular}

The data above (item No.19) showed that most of the students will be more active in English learning activity if the classroom is supported with complete tools. Where 420/480 $\mathrm{x} 100=87.5 \%$ and it categorized as very strong.

Table 20.I will be more active in learning English if the classroom has a good lighting, air, and temperature.

\begin{tabular}{ccccc}
\hline No & Classification & Score & Frequency & Sum of score \\
\hline 1 & Strongly agree (SA) & 5 & 47 & 235 \\
2 & Agree (A) & 4 & 38 & 152 \\
3 & Undecided (U) & 3 & 4 & 12 \\
4 & Disagree (D) & 2 & 5 & 10 \\
5 & Strongly disagree (SD) & 1 & 2 & 2 \\
\hline & Total & & 96 & 411 \\
\hline
\end{tabular}

The data above (item No.20) showed that the students will be more active in learning English if the classroom has a good lighting, air, and temperature. Where 411/480 $\mathrm{x} 100=85.62 \%$ and is categorized as very strong. 
Table 21.My curiosity will rise if the English learning is holding in a good layout classroom.

\begin{tabular}{ccccc}
\hline No & Classification & Score & Frequency & Sum of score \\
\hline 1 & Strongly agree (SA) & 5 & 24 & 120 \\
2 & Agree (A) & 4 & 54 & 216 \\
3 & Undecided (U) & 3 & 16 & 48 \\
4 & Disagree (D) & 2 & 1 & 2 \\
5 & Strongly disagree (SD) & 1 & 1 & 1 \\
\hline & Total & & 96 & 387 \\
\hline
\end{tabular}

The data above (item No.21) showed that the students' curiosity will rise if the English learning is holding in a good layout classroom. Where $387 / 480$ x $100=80.62 \%$ and it categorized as very strong.

Table 22.I will be more creative in learning English if the classroom supported with decent objects.

\begin{tabular}{ccccc}
\hline No & Classification & Score & Frequency & Sum of score \\
\hline 1 & Strongly agree (SA) & 5 & 23 & 115 \\
2 & Agree (A) & 4 & 58 & 232 \\
3 & Undecided (U) & 3 & 7 & 21 \\
4 & Disagree (D) & 2 & 6 & 12 \\
5 & Strongly disagree (SD) & 1 & 2 & 2 \\
\hline & Total & 96 & 382 \\
\hline
\end{tabular}

The data above (item No.22) showed that the classroom which is supported with decent objects will make the students more creative in learning English. Where 382/480 x $100=79.58 \%$ and it categorized as strong.

Table 23.I will be more motivated in learning English if the classroom has a good environment.

\begin{tabular}{ccccc}
\hline No & Classification & Score & Frequency & Sum of score \\
\hline 1 & Strongly agree (SA) & 5 & 39 & 195 \\
2 & Agree (A) & 4 & 48 & 192 \\
3 & Undecided (U) & 3 & 5 & 15 \\
4 & Disagree (D) & 2 & 4 & 8 \\
5 & Strongly disagree (SD) & 1 & 0 & 0 \\
\hline & Total & & 96 & 410 \\
\hline
\end{tabular}

The data above (item No.23) showed that most of the students will be more motivated in learning English if the classroom has a good environment. Where 410/480 x $100=85.41 \%$ and it categorized as very strong. 
Table 24.I will be more confident if the classroom has a good layout and environment.

\begin{tabular}{ccccc}
\hline No & Classification & Score & Frequency & Sum of score \\
\hline 1 & Strongly agree (SA) & 5 & 40 & 200 \\
2 & Agree (A) & 4 & 40 & 160 \\
3 & Undecided (U) & 3 & 11 & 33 \\
4 & Disagree (D) & 2 & 4 & 8 \\
5 & Strongly disagree (SD) & 1 & 1 & 1 \\
\hline & Total & & 96 & 402
\end{tabular}

The data above (item No.24) showed the students will be more confident if the classroom has a good layout and environment. Where $402 / 480 \times 100=83.75 \%$ and it categorized as very strong.

Recording to the result of ninety-six respondents that have done the questionnaire, the researcher found out that the classroom design gives the positive impact influence the students' interest in English learning activity.

\section{Discussion}

The classroom design can influence the students' learning activity related to their interest. The questionnaire items showed that most of the students agreed with the statements about the influence of classroom design on their interest.

The observation during the learning process told that the students gave positive interest during the class with a good classroom environment and layout. Unconsciously the classroom design has influenced the students' interest. It was proved by the students' readiness in receiving the material from the teacher. They also kept focused and being active in the learning activity. The researcher could see the difference between the first meeting and the last meeting even delivering the same material to the students. The students also have known the importance of classroom design to their learning process relating to their interest.

Besides, the result of the students' questionnaire showed that most of the student felt agree with all of the positive statements. The researcher took the data through a questionnaire after applying the classroom design concept to the students. Then, the percentage of the questionnaire was very strong which means the classroom design strongly influences the students' interest. 
From the data of the item number one, it showed that the total score of the statement is 413 from 96 respondents. To find the rate score of the item is by using the measurement of each highest score of the answers classification. For strongly agree, as mentioned before the score level of the answer is 5. So, the highest score for the answer of strongly agree from 96 respondents is $5 \times 96=480$. The same calculation is applied to the other answers classification. For the answer of agree is 4 x $96=384$, undecided is 3 x $96=288$, disagree is 2 x $96=192$, strongly disagree is $1 \times 96$. From all of the answer classification calculation, the item number one can be measured that the rate score of this item is 413 which means it is in the scale of strongly agree. So, it can be concluded that the rate of the respondents' response for the item number one classified strongly agree.

Based on the questionnaire, the calculation of the data analysis showed that the value of $r_{\text {count }}$ was greater than $r_{\text {table }}$ where $r_{\text {count }}=0.994$ and $r_{\text {table }}=0.201$ for level of significance 0,05 , it means the null hypothesis $\left(\mathrm{H}_{0}\right)$ was rejected and the alternative hypothesis $\left(\mathrm{H}_{\mathrm{a}}\right)$ was accepted. The conclusion is the classroom design influences the students' interest in English learning activity. The value of the regression equation where $a$ $=32.867$ and $b=0.434$. Refer to the formula of regression $Y^{\prime}=a+b X$, it can be found the regression equation line $Y^{\prime}=32.867+0.434 X$ or $\mathrm{SI}=32.867+0.434 \mathrm{CD}$. Then by comparing the value of the $t_{\text {count }}$ with the $t_{\text {table }}$, it can be also show the influence of the independent variable to the dependent variable. The value of $t_{\text {count }}=4.680$ and $t_{\text {table }}=$ 2.637 which means the value of $t_{\text {count }}$ is greater than the value of $t_{\text {table }}$. Whereas the value of sig. variable $\mathrm{CD}($ Classroom Design $)=0,000<0.05$ so $H_{0}$ is rejected which means that the independent variable (classroom design) has positive and significant influence to the dependent variable (students' interest).

Based on the findings through the questionnaire and the observation, it has been found that the classroom design has a positive and significant influence on the students' interest in English learning activity. The previous studies found that the classroom design affected the students' activity and has important roles during the learning process, then the present study has proved that the previous studies have the same result where the classroom design influence the students' interest. 


\section{Conclusion}

According to the finding of this study, the students' interest was positively affected by the classroom design not only by the result of the questionnaire but also during the meeting in the classroom by showing the students' interest and attention during the learning process.

In considering with the conclusion of this research, the writer further proposed some suggestions to the teacher, students and the next researcher as. For the English teacher, it's better to conduct the class by considering the classroom design concept, such as the environment and the layout in the classroom. Due to increasing the students' interest in learning English will bring them to the learning success. It is recommended to prepare the class well before teaching the students. For the students, they have present a good classroom environment by keeping the clean and not making noise during the class. They also can decorate their classroom with supporting object that can make them feel at ease in learning English while it can increase their interest. Besides, the students also should have some ways to increase their interest through the classroom design by presenting good environment in the classroom. Then researcher suggested to other researcher to conduct a further research about the importance of classroom that influence the students in learning English in order there will be more information about the classroom design roles. Last, the researcher hopes the result of this research can be used as an additional reference.

\section{References}

Cheryan, Sapna, et al., 2014. "Designing Classroom to Maximize Student Achievement", vol. 1. Published Journal: University of Washington: Seattle.

Steelcase Education. "How Classroom Design Affects Student Engagement". https://www.steelcase.com/content/uploads/2015/03/Post-OccupancyWhitepaper_FINAL.pdf. Accessed on May $4^{\text {th }} 2017$

Sugiono. 2014. MetodePenelitianPendidikanPendekatanKuantitatif, Kualitatif, $R \&$ D. Cet. XX; Bandung: Alfabeta.

Sugiono. 2002. StatistikauntukPenelitian. Cet. IV; Bandung: Alfabeta. 
Inspiring: English Education Journal

Volume I No 2 September2018 